\title{
Dampak Pengembangan Hidden Canyon Beji Guwang Sebagai Destinasi Wisata Terhadap Perekonomian Masyarakat Lokal Di Desa Guwang Kecamatan Sukawati Gianyar
}

Ayu Diva Septiyani Putri Sugianta a, 1, I Nyoman Sunarta a, 2

1 divaseptyani@gmail.com, ${ }^{2}$ nyoman_sunarta@unud.ac.id

a Program Studi S1 Destinasi Pariwisata, Fakultas Pariwisata,Universitas Udayana, Jl. Dr. R. Goris, Denpasar, Bali 80232 Indonesia

\section{Abstract}

Tourism is designed to be a number one source of foreign exchange in Indonesia. But the development of toursm and tourist destination will definitely have an economic impact whether it's positive impact or negative impact. As well as development in tourist destination Hidden Canyon Beji Guwang. This research aims to find out what is the participation of local community in the development of Hidden Canyon Beji Guwang and to find out what is the economic impact of it.

The data used in this research is qualitative and quantitative data. Primary data source data and secondary data source. This research used descriptive qualitative method. Which is obtained through observation, in-depth interviews and documentation. Informant determination is done by purposive sampling technique.

The results of this research is tourist destination Hidden Canyon Beji Guwang management derived entirely from the participation of local communities in Desa Guwang. Economic impact which is more dominantly felt by the local communities because the management system is only employs local people from Guwang Village whose most of them are dropped out of school.

Keywords: Economic Impact, Participation of Local Communities, Tourism Destination, Hidden Canyon Beji Guwang

\section{PENDAHULUAN}

Pulau Bali memiliki potensi wisata yang sangat beragam sehingga tidak mengherankan apabila Bali setiap tahunnya selalu didatangi oleh berjuta wisatawan mancanegara. Hal ini menyebabkan pembangunan dan perkembangan dalam bidang industri pariwisata juga meningkat pesat. Banyak usaha-usaha pariwisata dan destinasi-destinasi baru bermunculan dan tersebar diseluruh kabupaten yang ada di Bali. Pariwisata nasional dirancangkan agar dapat menjadi sumber dari penghasil devisa utama di Indonesia. Namun pembangunan suatu daya tarik wisata ataupun pengembangan kepariwisataan itu sendiri membawa konsikuensi atau dampak yang ditimbulkan baik itu positif maupun negatif. Salah satu dampak yang ditimbulkan akibat pengembangan pariwisata ini ialah dampak ekonomi.

Penelitian tentang dampak ekonomi dibidang pariwisata penting dilakukan agar daerah dimana pariwisata tersebut berkembang benar-benar sadar dan mengetahui dengan jelas apa saja yang akan terjadi apabila pariwisata tersebut akan dibangun dan dikembangkan di daerah mereka. Selain itu perlu diteliti tentang partisipasi masyarakat agar dapat mengetahui upaya apa saja yang dilakukan oleh masyarakat lokal dalam mengembangkan destinasi wisata di daerahnya.

Kabupaten Gianyar merupakan salah satu kabupaten yang memiliki banyak jenis potensi wisata. Gianyar menjadi salah satu kabupaten yang wajib dikunjungi bila berwisata ke Bali. Salah satu daerah di Gianyar yang sering dikunjungi oleh wisatawan ialah Sukawati.

Sukawati menjadi sangat terkenal dan banyak dikunjungi karena pasarnya yang terkenal, pasar sukawati menjualkan berbagai karya seni, oleh-oleh khas ataupun kerajinan tangan unik dan menarik. Pasar ini sudah ada sejak lama, tetapi baru di tahun 1980 pasar ini mulai menjual kerajinan ataupun oleholeh khas yang menarik wisatawan untuk berkunjung. Namun dibalik pasar seninya yang terkenal itu, Kecamatan Sukawati menyimpan potensi alam yang sangat indah dan baru saja dikembangkan yaitu Hidden Canyon Beji Guwang.

Hidden Canyon Beji Guwang adalah sebuah fenomena alam aliran sungai dengan 
dibentengi tebing batu tajam di kanan dan kirinya. Kata beji sendiri berarti air mancur yang dimurnikan oleh penduduk atau warga setempat. Tebing dan dinding batu tersebut berbentuk dan bermotif sangat indah karena terkikis oleh air sungai yang terjadi selama ratusan ribu tahun. Hidden Canyon ini baru populer sejak tiga tahun yang lalu tepatnya di tahun 2015, karena tempat ini awalnya dirahasiakan dan hanya diketahui oleh penduduk setempat, seiring berjalannya waktu warga setempat memutuskan untuk membuka Hidden Canyon ini untuk para wisatawan baik lokal maupun mancanegara dengan tujuan untuk meningkatkan pendapatan desa juga pendapatan masyarakat lokal sebagai salah satu daya tarik wisata yang ada di Bali.

Untuk itu, peneliti memutuskan untuk memilih topik yaitu "Dampak Pengembangan Hidden Canyon Sebagai Destinasi Wisata terhadap Perekonomian Masyarakat Lokal di Desa Guwang Kecamatan Sukawati Gianyar" dengan begitu, peneliti berharap dengan dilakukan penelitian ini kita dapat melihat seberapa besar dampak ekonomi yang dirasakan masyarakat lokal akibat pengembangan pariwisata di Hidden Canyon tersebut, mengingat bahwa Hidden Canyon merupakan salah satu destinasi yang baru saja dikembangkan pada tahun 2015 yang lalu. Tidak hanya sampai disitu, dengan dilakukannya penelitian ini diharapkan juga dapat menjadi salah satu contoh dalam pengembangan serta pengelolaan daya tarik wisata lainnya secara umum di Bali serta secara khusus di Kabupaten Gianyar. Peneliti juga ingin membahas tentang partisipasi dari masyarakat lokal sekitar daya tarik wisata tersebut karena masyarakat lokal terutama masyarakat yang ikut langsung berpartisipasi dalam mengembangkan Daya Tarik Wisata Hidden Canyon Beji Guwang adalah pihak yang akan merasakan dampak ekonomi yang terjadi akibat adanya destinasi wisata baru di Desa mereka.

\section{KEPUSTAKAAN}

\subsection{Tinjauan Penelitian Sebelumnya}

Penelitian yang digunakan sebagai bahan acuan adalah penelitian yang dilakukan oleh Hermawan (2017) yang berjudul "Dampak Pengembangan Desa
Wisata Nglanggeran Terhadap Ekonomi Masyarakat Lokal". Penelitian tersebut mendapatkan hasil bahwa aktifitas pengembangan Desa Wisata Nglanggeran dinilai cukup baik, indikatornya utama adalah rata-rata kenaikan kunjungan wisatawan yang cukup besar dari tahun ke tahun. Hasil penelitian menunjukan bahwa pengembagan desa wisata membawa dampak yang positif bagi perkembangan ekonomi masyarakat lokal di Desa Nglanggeran, diantaranya: penghasilan masyarakat meningkat; meningkatkan peluang kerja dan berusaha; meningkatkan kepemilikan dan kontrol masyarakat lokal; meningkatkan pendapatan pemerintah melalui retribusi wisata. Sedangkan indikas dampak negatif terhadap ekonomi lokal berupa kenaikan harga barang tidak ditemukan

\subsection{Tinjauan Konsep}

\subsubsection{Konsep Dampak Ekonomi Pariwisata}

Adapun dampak positif ekonomi yang didapat dari pariwisata antara lain: pendapatan dari usaha bisnis pariwisata pendapatan pemerintah, penyerapan tenaga kerja, multiplier effects, dan pemanfaatan fasilitas pariwisata oleh masyarakat lokal Pitana (2009).

\subsubsection{Konsep Partisipasi Masyarakat}

Partisipasi masyarakat adalah keikutsertaan masyarakat dalam proses pengidentifikasian masalah dan potensi yang ada di masyarakat dalam proses mengevaluasi perubahan yang terjadi Deviyanti (2013). Adanya beberapa bentuk partisipasi antara lain: partisipasi dalam bentuk tenaga, partisipasi dalam bentuk uang, partisipasi dalam bentuk harta benda Deviyanti (2013).

\subsubsection{Konsep Usaha Pariwisata}

Usaha pariwisata adalah usaha yang menyediakan barang dan atau jasa bagi pemenuhan kebutuhan wisatawan dan penyeleggaraan pariwisata (UndangUndang Republik Indonesia No.10 Bab I pasal 1 ayat 7,2009 ). Usaha pariwisata meliputi antara lain: daya tarik wisata, kawasan pariwisata, jasa transportasi pariwisata, jasa perjalanan pariwisata, jasa 
makanan dan minuman, penyediaan akomodasi, penyelenggaraan kegiatan hiburan dan rekreasi, penyelenggaraan pertemuan, perjalanan insentif, konfrensi dan pameran, jasa informasi pariwisata, jasa konsultan pariwisata, jasa pramuwisata, wisata tirta dan spa (Undang-Undang Republik Indonesia No.10 Bab IV pasal 14 ayat 1,2009 ).

\section{METODE PENELITIAN}

Lokasi penelitian terletak di Hidden Canyon Beji Guwang Desa Guwang Kecamatan Sukawati Kabupaten Gianyar Provinsi Bali. Adapun batas-batas letak wilayah Hidden Canyon ialah: di arah utara utara dibatasi oleh Sungai Cengcengan, di timur dibatasi oleh Pura Dalem dan Pura Prajapati Guwang, di barat dibatasi oleh Pura Beji Seme dan di selatan dibatasi oleh Pura Gladug.

Ruang lingkup penelitian ini adalah partisipasi masyarakat desa guwang dalam bentuk tenaga uang dan harta benda dan dampak pariwisata dalam sektor ekonomi yang dilihat dari: pendapatan dari usaha bisnis pariwisata, pendapatan pemerintah, penyerapan tenaga kerja, multiplier effects, dan pemanfaatan fasilitas pariwisata oleh masyarakat lokal.

Jenis data dalam penelitian ini adalah data kualitatif. Sumber data dalam penelitian menurut meliputi data primer dan data sekunder. Teknik pengumpulan data dalam penelitian ini adalah observasi, wawancara dan studi dokumentasi. Teknik penentuan informan dalam penelitian ini adalah purposive sampling Bungin (2007).

\section{HASIL DAN PEMBAHASAN}

\subsection{Bentuk Partisipasi Masyarakat Lokal Desa Guwang dalam Pengembangan Daya Tarik Wisata Hidden Canyon Beji Guwang \\ Didalam pengembangan daya tarik} wisata Hidden Canyon Beji Guwang ini, sangat dapat dilihat sekali dari keterlibatan dan partisipasi masyarakat setempat secara langsung mengembangkan daya tarik wisata tersebut, dimana masyarakat lokal Desa Guwang ini berpartisipasi secara penuh didalam pengembangan daya tarik ini. Mulai dari pekerja-pekerja yang ada hingga pengelola daya tarik tersebut merupakan 100 persen masyarakat lokal Desa Guwang. Berdasarkan bentuk partisipasi yang dilakukan oleh masyarakat lokal setempat, dapat dikelompokkan menjadi tiga jenis yaitu partisipasi dalam bentuk tenaga, partisipasi dalam bentuk uang, dan partisipasi dalam bentuk harta benda yang dapat dijelaskan sebagai berikut:

\section{a. Partisipasi dalam Bentuk Tenaga}

Masyarakat lokal yang berpartisipasi di daya tarik wisata Hidden Canyon Beji Guwang ini memberikan sumbangan tenaganya guna untuk mengembangkan dan mengelola daya tarik wisata Hidden Canyon Beji Guwang. Masyarakat yang berpartisipasi dan bekerja secara langsung dalam hal pengembangan daya tarik disana dilibatkan didalam dua tugas yaitu tugas didalam bidang staff dan didalam bidang guiding para wisatawan yang datang. Untuk pekerjaan staff dibagi lagi menjadi dua bagian yaitu bagian front office dan bagian bendahara. Dimana tugas untuk pekerja yang menjadi front office tersebut ialah memberikan penjelasan umum tentang daya tarik wisata Hidden Canyon Beji Guwang, menyambut para wisatawan baik wisatawan lokal maupun wisatawan mancanegara yang datang dan berkunjung kesana, merobek serta memberikan karcis tiket masuk atraksi wisata, memberikan pengarahan pada wisatawan tentang fasilitas-fasilitas yang dimiliki oleh daya tarik wisata Hidden Canyon Beji Guwang, menawarkan jasa guide kepada wisatawan. Sedangkan tugas dari pekerja yang menjadi bendahara ialah mencatat hasil dari pendapatan sehari-harinya didalam pembukuan yang telah disiapkan sehingga hasil penjualan tiket tersebut dapat dipertanggung jawabkan ke desa adat maupun desa dinas setempat.

Sedangkan untuk yang bekerja menjadi guide bagi para wisatawan yang datang memiliki tugas atau peranan dalam hal mengantar dan membantu wisatawan turun langsung ke tebing, menjelaskan lebih rinci segala sesuatu tentang Hidden Canyon Beji Guwang, membawa barang-barang yang dititipkan oleh para wisatawan seperti tas, sandal dan lain-lain, membantu wisatawan 
mengambil foto atau gambar bila diinginkan. Tugas para guide ini sangatlah penting karena mengingat tebing dari daya tarik wisata Hidden Canyon ini sangatlah terjal sehingga wisatawan yang datang bisa dikatakan sulit untuk melewati medan dari tebing-tebing yang ada dan bisa saja terjadi kecelakaan seperti tergelincir dan lain sebagainya apabila tidak menggunakan jasa guide yang sudah berpengalaman dan tahu secara jelas tentang apa saja yang harus dilakukan agar bisa melewati medan-medan yang ada disana.

Untuk pekerja yang bertugas sebagai guide di daya tarik wisata Hidden Canyon Beji Guwang ini dibagi menjadi dua shift yakni shift A dan shift B. Dimana kedua shift tersebut melakukan kewajiban mereka bekerja secara bergantian setiap harinya misalnya shift A bekerja di hari Senin, maka shift B akan bekerja di hari selasa dan begitu seterusnya.

Jika pengunjung melebihi kapasitas guide yang bertugas dimana biasanya terjadi pada akhir pecan yakni hari Jumat, Sabtu dan Minggu maka para guide yang bertugas pada hari tersebut akan dibantu oleh para guide yang sedang tidak bekerja atau libur, biasanya akan diberikan informasi atau himbauan oleh para staff dan pengelola apabila terjadinya kelebihan kapasitas pengunjung. Jumlah para guide yang bertugas di daya tarik wisata Hidden Canyon Beji Guwang ini ialah 35 orang dimana pekerja yang datang perhari tergantung shift apa yang mendapat giliran. Shift A memiliki total jumlah pekerja 17 orang sedangkan shift B memiliki total jumlah pekerja 18 orang.

Masyarakat lokal juga ada yang berpartisipasi didalam hal pemenuhan kebutuhan dan fasilitas di daya tarik wisata Hidden Canyon Beji Guwang. Pedagang dan juru parkir yang ada di dalam areal maupun diluar Hidden Canyon Beji Guwang juga merupakan masyarakat lokal Desa Guwang. Dimana masyarakat yang berpartisipasi sebagai pedagang membuka kios-kios yang menjualkan makanan seperti nasi goreng, tipat cantok, nasi campur dll. Ada juga pedagang yang menawarkan makanan ringan seperti snack dan minuman. Jumlah kios atau warung yang ada di Hidden Canyon
Beji Guwang tersebut ialah enam kios. Tidak hanya menjual makanan dan minuman, ada juga masyarakat lokal yang menjual oleholeh seperti sarung, celana dan baju yang diproduksi ataupun yang diambil dari pasar seni Guwang.

Masyarakat lokal yang berprofesi sebagai petani disekitar wilayah daya tarik wisata Hidden Canyon Beji Guwang juga ikut berpartisipasi dengan cara menawarkan hasil panen yang mereka miliki kepada pengunjung yang baru saja keluar dari tebing Hidden Canyon tersebut mengingat bahwa setelah keluar dari areal tebing, pengunjung harus melewati hamparan sawah milik masyarakat lokal yang masih sangat asri sehingga rasa lelah sehabis trekking di tebing Hidden Canyon menjadi tidak terasa. Panen yang mereka hasilkan bisa dipetik bersama dengan pengunjung daya tarik wisata Hidden Canyon Beji Guwang. Tanaman yang dihasilkan oleh petani setempat antara lain: padi, palawija, semangka, timun, dan bunga yang semuanya bisa dipetik secara langsung sesuai persetujuan yang telah dibuat diantara petani dan para wisatawan. Jika wisatawan tersebut tertarik dan ingin membeli hasil usaha tani masyarakat lokal setempat, maka masyarakat lokal yang menjual hasil tani tersebutlah yang akan memberikan biaya. Biaya yang dikenakan merupakan asli dari hasil panen tersebut maksudnya, pengelola dan pihak-pihak dari daya tarik wisata Hidden Canyon Beji Guwang tidak ada menambahkan harga yang harus dibayarkan. Namun ada perbedaan harga penjualan hasil tani jika dibeli oleh wisatawan asing atau mancanegara.

Sedangkan, untuk yang mengelola daya tarik wisata Hidden Canyon Beji Guwang tersebut Desa telah membentuk tim persiapan yang ditetapkan berdasarkan Keputusan Perbekel Desa Guwang Nomor 13 Tahun 2015 yang dikeluarkan tepatnya pada tanggal 5 Oktober 2015. Dimana pengelola memiliki tugas merencanakan, mengorganisasikan, menggerakan orangorang yang bekerja disana dan juga mengawasi segala sesuatu yang berhubungan dengan daya tarik wisata Hidden Canyon Beji Guwang tersebut. Namun struktur tim persiapan tersebut 
masih dalam bentuk sementara sampai dengan daya tarik wisata Hidden Canyon Beji Guwang ini telah siap dan terpenuhi semua fasilitasnya sesuai dengan harapan bersama. Setiap akhir tahun akan diadakan rapat evaluasi yang akan diadakan bersama seluruh tim persiapan dan juga Kepala Desa Guwang serta Bendesa Adat Guwang untuk menilai sejauh mana perkembangan yang telah dicapai.

\section{b. Partisipasi dalam Bentuk Uang}

Partisipasi yang dimaksud disini ialah apa saja yang diberikan masyarakat Desa Guwang untuk memperlancar usaha yang diberikan dalam bentuk uang ataupun sumbangan untuk pembangunan daya tarik wisata Hidden Canyon Beji Guwang. Pada awal mula pengembangan daya tarik wisata Hidden Canyon Beji Guwang ini, masyarakat lokal Desa Guwang dimana didalamnya ada tujuh banjar dinas dan lima banjar adat setempat melakukan sumbangan dan bantuan yang dimanfaatkan oleh perbekel Desa Guwang untuk membangun sarana, prasarana serta fasilitas yang mencukupi untuk dijalankannya daya tarik wisata Hidden Canyon Beji Guwang ini. Serta ada pula bantuan berupa dana yang didapat dari APBDes (Anggaran Pendapatan dan Belanja Desa) dan Pemerintah Kabupaten Gianyar yang digunakan untuk membuan jalan pedestrian di subak atau sawah sepanjang 1,25 kilometer serta pembangunan fasilitasfasilitas lainnya.

\section{c. Partisipasi dalam Bentuk Harta Benda}

Partisipasi yang dilakukan oleh masyarakat Desa Guwang dalam bentuk harta benda demi menunjang pengembangan daya tarik wisata Hidden Canyon Beji Guwang adalah berupa peralatan kerja seperti sapu, sabit, cangkul, palu, dan gergaji yang disumbangkan dengan tujuan agar memudahkan masyarakat yang lokal yang bekerja disana maupun yang tidak bekerja di daya tarik wisata Hidden Canyon Beji Guwang dapat melakukan pembersihan dan perawatan disepanjang areal daya tarik wisata Hidden Canyon Beji Guwang. Alat-alat tersebut dikumpulkan pada awal berdirinya Hidden Canyon Beji Guwang tahun 2015 dimana masyarakat lokal bergotong-royong bersama-sama membersihkan areal daya tarik wisata tersebut.

\subsection{Dampak Ekonomi Bagi Masyarakat Lokal Desa Guwang Akibat Pengembangan Daya Tarik Wisata Hidden Canyon Beji Guwang}

Pengembangan suatu daya tarik wisata pasti tidak luput dengan adanya suatu dampak yang ditimbulkan akibat pengembangan suatu daya tarik tersebut. Salah satu dampak yang diperoleh dari pengembangan daya tarik wisata Hidden Canyon Beji Guwang ialah dampak ekonomi. Namun karena daya tarik wisata ini masih baru saja dikembangkan dan disiapkan oleh Desa Adat dan Desa Dinas Guwang, maka dampak ekonomi yang terjadi akibat pengembangan daya tarik tersebut yang muncul hanya baru dampak positifnya. Dampak-dampak positif dalam bidang perekonomian yang timbul akibat adanya suatu kegiatan pariwisata dapat dibedakan menjadi lima jenis yaitu: pendapatan dari usaha bisnis pariwisata, pendapatan pemerintah, penyerapan tenaga kerja, multiplier effects, dan pemanfaatan fasilitas pariwisata oleh masyarakat lokal yang dapat dijelaskan sebagai berikut:

a. Pendapatan dari Usaha Bisnis Pariwisata Pengembangan daya tarik wisata Hidden Canyon Beji Guwang ini menimbulkan dampak positif bagi perekonomian bisnis pariwisata yang ada disana. Harga tiket untuk masuk ke areal daya tarik wisata ini ialah Rp. 15.000,- harga tiket tersebut sudah termasuk biaya parkir, penggunaan fasilitas toilet dan loker yang disediakan disana. Hidden Canyon Beji Guwang ini juga menerima wisatawan yang datang dan memiliki tujuan khusus untuk melakukan pemotretan pernikahan atau prewedding yang akan dikenakan tarif biaya sebesar Rp. 300.000,- namun, untuk wisatawan yang datang dengan tujuan pemotretan prewedding tidak diperkenankan datang saat akhir pekan karena ramainya pengunjung yang datang sehingga nantinya akan menyebabkan perasaan kurangnya kenyamanan para pengunjung. Pemungutan tiket ini tidak 
berlangsung atau berlaku dari awal diresmikannya daya tarik wisata Hidden Canyon Beji Guwang ini, baru di tahun 2016 tepatnya bulan November diadakanya pemungutan karcis tiket masuk sebesar Rp. 15.000,- tersebut. Pada awalnya di tahun 2015 bulan Oktober hingga 2016 bulan Oktober, pengunjung dan wisatawan yang datang mengunjungi Hidden Canyon Beji Guwang tersebut hanya memberikan sumbangan sukarela atau donasi karena masih dianggap sebagai awal mula atau percobaan untuk melihat sejauh mana keberhasilan dari pengembangan tersebut. Setiap harinya, rata-rata jumlah kunjungan wisatawan baik wisatawan lokal maupun mancanegara ke daya tarik wisata Hidden Canyon Beji Guwang ini bisa mencapai jumlah maksimal 150 hingga 200 orang di hari biasa dan jika di akhir pekan atau hari libur, pengunjung yang datang bisa mencapai jumlah maksimal 200 hingga 400 orang.

Kunjungan wisatawan perbulannya yang datang ke daya tarik wisata Hidden Canyon Beji Guwang tersebut tidak menentu dimana jumlah kunjungan wisatawan yang datang dipengaruhi oleh hari-hari tertentu seperti hari libur nasional, hari raya agama dll. Belum lagi apabila air sungai yang ada di Hidden Canyon tersebut sedang tinggi maka daya tarik wisata Hidden Canyon Beji Guwang ini terpaksa harus ditutup. Biasanya wisatawan yang melakukan pemotretan prewedding di daya tarik wisata Hidden Canyon Beji Guwang ini, sudah datang dengan membawa photographer dan kelengkapan yang diperlukan. Pihak Hidden Canyon Beji Guwang tidak menyiapkan jasajasa tersebut. Sehingga wisatawan hanya membayar biaya masuk saja sebesar $\mathrm{Rp}$. 300.000 tersebut.

Pengeluaran dari para wisatawan tersebut secara langsung maupun tidak langsung merupakan sumber pendapatan utama bagi daya tarik wisata Hidden Canyon Beji Guwang sebagai salah satu usaha bisnis pariwisata. Pendapatan tersebut sebagaiannya digunakan untuk pemberian upah para staff dan pembenahanpembenahan maupun pembangunan sarana, prasarana dan fasilitas yang ada di daya tarik wisata Hidden Canyon Beji Guwang.

\section{b. Pendapatan Pemerintah}

Adanya usaha pariwisata dalam bentuk daya tarik wisata Hidden Canyon Beji Guwang pasti juga akan berdampak kepada pendapatan pemerintah baik itu ditingkat desa, kabupaten maupun provinsi. Namun saat daya tarik wisata Hidden Canyon Beji Guwang ini pertama kali dikembangkan oleh Desa Dinas Guwang dan Desa Adat Guwang, telah diadakannya rapat bersama dan menghasilkan persetujuan dimana dibentuknya tim persiapan yang memiliki fungsi serta tujuan untuk mengelola dan mempersiapkan pengembangan daya tarik wisata Hidden Canyon Beji Guwang karena pengembangan tersebut masih bersifat percobaan. Tim persiapan ini akan terus dipantau kinerjanya bersama baik itu oleh pemerintah maupun masyarakat setempat. Tim persiapan akan terus ditetapkan sebagai pengelola daya tarik wisata Hidden Canyon Beji Guwang sampai pada saatnya dirasa segala jenis persiapan, fasilitas, dan sarana sudah memenuhi standar yang telah ditetapkan.

Disini Desa Dinas dan Desa Adat Guwang telah membuat persetujuan agar semua hasil pendapatan yang diperoleh dari usaha pariwisata Hidden Canyon Beji Guwang tersebut dikelola oleh tim persiapan dengan catatan tim persiapan tersebut harus memperlihatkan sepenuhnya pembukuan yang menyangkut pendapatan daya tarik wisata Hidden Canyon Beji Guwang. Sehingga dampak ekonomi yang ditimbulkan akibat adanya daya tarik wisata Hidden Canyon Beji Guwang terhadap pendapatan pemerintah belum terlalu terlihat sampai saat ini. Namun kepala desa yakin bahwa kedepannya setelah daya tarik wisata Hidden Canyon Beji Guwang ini siap secara penuh dan sudah berjalan sistem pembagian hasil antara desa, pengelola dan masyarakat yang bekerja disana, daya tarik wisata Hidden Canyon Beji Guwang ini akan berdampak sangat besar bagi pendapatan ekonomi Desa Guwang. Setiap tahunnya di bulan Oktober akan diadakan rapat oleh kepala desa, bendesa adat, dan klian-klian setempat serta tim persiapan, dimana didalam rapat tersebut tim persiapan akan hadir dan mempertanggungjawabkan 
tugasnya dengan mempaparkan laporan tentang segala sesuatu yang berhubungan dengan daya tarik wisata Hidden Canyon Beji Guwang setahun terakhir. Didalam rapat tersebutlah akan dipaparkan keputusan selanjutnya mengenai pengelolaan daya tarik wisata Hidden Canyon Beji Guwang.

Untuk pemerintah di tingkat provinsi maupun kabupaten, sampai saat ini belum ada melakukan perundingan dan persetujuan tentang kerjasama atau hubungan dengan daya tarik wisata Hidden Canyon Beji Guwang. Pemerintah baik itu dari tingkat polsek, tni, kepolisian, camat, Dinas Pariwisata Kabupaten Gianyar, Dinas Pariwisata Provinsi tamu-tamu dari pemerintah pusat sudah pernah berkunjung dan memberikan kontribusi berupa ide-ide dan gagasan yang dapat menjadi bahan pemikiran untuk pengembangan daya tarik wisata Hidden Canyon Beji Guwang. Selain menggunakan dana dari desa, Pemerintah Kabupaten pernah memberikan kontrubusi sumbangan berupa dana untuk memperbaiki lingkungan Canyon tersebut. Dan apabila nanti ada bantuan atau kontribusi yang datang misalnya berupa tangga atau tali yang bertujuan agar memudahkan wisatawan yang berkunjung pada saat air sungai pasang, tali dan tangga tersebut tidak akan menggangu pemandangan asli dari Hidden Canyon Beji Guwang tersebut. Pihak desa dan para pengelola serta masyarakat yang bekerja di Hidden Canyon Beji Guwang berharap agar bisa mendapat asuransi keselamatan dari pemerintah agar tidak berdampak negatif. Namun tampaknya hal yang diharapkan tersebut masih belum bisa terpenuhi akibat adanya kendala dalam masalah finansial Desa Guwang dan kurangnya komunikasi yang lebih dengan pemerintah pusat.

\section{c. Penyerapan Tenaga Kerja}

Adanya daya tarik wisata Hidden Canyon Beji Guwang ini sudah sangat pasti berdampak pada penyerapan tenaga kerja. Apalagi setelah apa yang sudah dibahas sebelumnya, bahwa tenaga kerja yang ikut serta berpartisipasi seperti mengelola, menjadi guide, menjadi staff, pedagang, tukang parkir dan lain sebagainya merupakan 100 persen tenaga kerja yang berasal dari Desa Guwang yang didalamnya dibagi menjadi tujuh banjar dinas dan lima banjar adat tersebut. Walaupun Hidden Canyon Beji Guwang ini letaknya dekat dengan Banjar Wangbung dan Banjar Buluh, namun baik pekerja, pengelola, pedagang dan pihak-pihak lain yang mencari rejeki di daya tarik wisata Hidden Canyon Beji Guwang tersebut tidak hanya berasal dari kedua banjar tersebut. Sehingga tujuan dikembangkannya Hidden Canyon Beji Guwang yakni untuk mensejahterakan masyarakat lokal Desa Guwang bisa dipenuhi.

Untuk para pekerja yang ada disana, hanya diambil masyarakat asli Desa Guwang yang putus sekolah baik itu SD, SMP, SMA yang memiliki niat yang tinggi untuk bekerja dengan tujuan agar berkurangnya pengangguran di Desa Guwang yang disebabkan oleh kurangnya jenjang pendidikan. Total semua pekerja berjumlah 38 orang dimana guide yang ada berjumlah 35 dan staff dua orang dan tukang parkir yang berjumlah satu orang. Sedangkan untuk para pedagang tetap yang menjualkan barang dagangan berupa makanan dan minuman berjumlah enam kios atau warung

Pemberian upah, guide mendapat upah dari hasil melayani dan menghantar wisatawan yang langsung diberikan oleh wisatawan tersebut seikhlasnya, tidak ada patokan harga jika ingin menyewa guide yang ada. Hasil dari jasa melayani dan menghantar wisatawan sepenuhnya milik guide atau tidak ada lagi dibagikan ke pihakpihak lain. Berdasarkan wawancara yang dilakukan, upah rata-rata perbulan yang didapatkan oleh para guide yang bekerja di daya tarik wisata Hidden Canyon Beji Guwang tersebut sebesar Rp. 1.500 .000 sampai dengan Rp. 2.000.000. Sedangkan untuk para staff seperti bendahara dan front office yang ada disana diberikan upah atau gaji sebesar Rp. 1.500 .000 setiap bulannya. Karena parkir di daya tarik wisata Hidden Canyon Beji Guwang ini tidak dikenakan atau sudah include di tiket masuk, maka petugas parkir diberikan gaji atau upah sebesar Rp. 1.050.000. Semua masyarakat lokaln yang berpartisipasi sebagai pekerja 
di daya tarik wisata Hidden Canyon Beji Guwang kecuali yang bekerja menjadi pedagang adalah merupakan laki-laki.

Hal tersebut dapat dikatakan sebagai dampak ekonomi yang sifatnya positif untuk masyarakat lokal Desa Guwang akibat dari pengembangan daya tarik wisata Hidden Canyon Beji Guwang tersebut. Masyarakat lokal Desa Guwang yang putus sekolah tersebut rata-rata awalnya merupakan orang-orang yang tidak memiliki pekerjaan atau pengangguran, pekerja serabutan, dan bekerja freelance yang mendapat upah ratarata sekitar Rp. 500.000 sampai dengan Rp.1.000.000 perbulannya, masyarakat tersebut juga masih minim sekali pengetahuannya dibidang usaha pariwisata.

Diawal pengembangan daya tarik wisata Hidden Canyon Beji Guwang, tim persiapan selaku pengelola mengaku ada kendala untuk menggerakan para pekerja untuk melayani tamu yang datang karena ada kendala pada sisi pendidikan banyak yang tidak tamat atau lulus sekolah maka pekerja terkadang kesulitan untuk berinteraksi kepada tamu. Maka awal penerimaan pekerja akan dilatih dibidang bahasa, etika, disiplin dan lain-lain. Untuk sementara masyarakat yang ingin bekerja dan berpartisipasi pada daya tarik wisata Hidden Canyon Beji Guwang ini belum bisa semuanya di recruit atau langsung dimasukkan, hal ini karena dikhawatirkannya terlalu banyak quota pekerja yang melebihi jumlah wisatawan yang datang. Kendala yang dirasakan bukan hanya dari pihak pekerja saja namun ada juga kendala yang berasal dari beberapa wisatawan yang bersikeras untuk tidak memakai jasa guide dengan alasan sudah sering melakukan kegiatan wisata petualang seperti naik gunung dan lain-lain namun medan dan tanjakan yang ada di daya tarik wisata Hidden Canyon Beji Guwang ini jauh berbeda dibandingkan kegiatan wisata petualang lainnya, karena tebingnya yang tinggi dan medannya yang susah beberapa wisatawan yang menolak menggunakan guide sering terjatuh diperjalanan.

\section{d. Multiplier Effects}

Pengembangan daya tarik wisata Hidden Canyon Beji Guwang juga memicu perkembangan dan pertumbuhan ekonomi di daerah sekitar. Usaha perdagangan baik itu makanan maupun barang dagang seperti oleh-oleh disekitar daya tarik wisata Hidden Canyon Beji Guwang juga mendapat peningkatan hasil penjualan yang cukup signifikan karena wisatawan atau pengunjung biasanya setelah lelah melakukan trekking di tebing Hidden Canyon Beji Guwang pasti membeli sesuatu untuk dinikmati maupun dibawa pulang seperti makanan ataupun minuman atau bahkan oleh-oleh yang ditawarkan seperti sarung sepulang dari wisatawan melakukan trekking. Usaha tani di sekitar daya tarik wisata Hidden Canyon Beji Guwang tersebut juga mengalami peningkatan dibidang pendapatannya akibat ada sebagaian wisatawan yang melewati usaha tani mereka ketika pulang dari jalur trekking, membeli sesuatu yang dipanenkan oleh para petani tersebut.

Usaha Pasar Seni Guwang yang lokasinya tidak jauh dari daya tarik wisata Hidden Canyon Beji Guwang juga mengalami peningkatan wisatawan yang datang serta mengalami peningkatan pendapatan. Jasa transportasi pariwisata seperti travel yang berada di Desa Guwang juga mendapatkan peningkatan permintaan jasa transportasi.

\section{e. Pemanfaatan Fasilitas Pariwisata Oleh Masyarakat Lokal}

Mulai dikembangkannya daya tarik wisata Hidden Canyon Beji Guwang pada bulan Oktober 2015, terjadi banyak pembenahan-pembenahan di sekitar areal maupun diluar areal daya tarik wisata tersebut. Apalagi dengan adanya program pemerintah Desa Dinas Guwang yang menginginkan adanya pembenahan fasilitas penunjang pariwisata dan perbaikan usaha tani yang akan berdampak kepada pemanfaatan fasilitas pariwisata oleh masyarakat lokal setempat. Pembangunan fasilitas umum maupun fasilitas penunjang pariwisata sangat bermanfaat untuk masyarakat lokal. Dimana masyarakat lokal setempat selalu mengadakan odalan setiap enam bulan sekali yakni jatuh tepatnya pada rahinan kuningan dan adanya upacara pengabenan yang bisa menjadi daya tarik tersendiri diluar daya tarik utama untuk 
pengunjung yang ingin tahu dan melihat bagaimana upacara-upacara adat yang berlangsung. Mengingat bahwa disekitar daya tarik wisata Hidden Canyon Beji Guwang ini ada banyak pura seperti Pura Dalem, Pura Prajapati Guwang, Pura Beji Seme dan Pura Gladug maka dengan adanya pembenahan-pembenahan tersebut masyarakat akan lebih dimudahkan dan lebih nyaman saat melakukan persembahyangan disana. Selain itu, masyarakat yang menjadi petani juga diuntungkan, dengan adanya pembangunan fasilitas berupa vaping yang akan dilewati oleh para wisatawan ketika keluar dari tebing Hidden Canyon Beji Guwang, vaping yang dibangun dengan melewati sawah mereka menyebabkan sebagaian wisatawan tertarik dan ingin ikut memanen hasil yang mereka tanam. Pembangunan dan pemanfaatan fasilitas tersebut berdampak positif kepada pendapatan para petani disekitar areal daya tarik wisata Hidden Canyon Beji Guwang.

Sejauh ini fasilitas dan sarana yang sudah dibangun adalah pembenahan area parkir, pembangunan toilet, pembuatan loker, pembuatan jalan disekitar area jalan masuk ke daya tarik wisata Hidden Canyon Beji Guwang, pemberian tanaman hias seperti pepohonan dan bunga-bunga disekitar area tersebut, pembuatan vaping di jalan keluar dari area tebing Hidden Canyon menuju ke ladang sawah milik petani. Jika nantinya kerjasama yang dilakukan oleh para pihak daya tarik wisata Hidden Canyon Beji Guwang cocok dengan pemilik lahan, akan dibangun sebuah fasilitas atau sebuah atraksi baru yaitu flying fox. Melihat respon yang sangat positif terhadap area persawahan yang didapat dari para wisatawan yang berkunjung, tim persiapan akan lebih meningkatkan atau memfokuskan pada usaha tani milik masyarakat lokal sekitar, rencana kedepannya wisatawan bisa melihat atraksi baru seperti saat menbajak sawah akan di berikan aksi mepantigan yang bisa dilihat pada saat-saat tertentu. Tim persiapan juga berkeinginan untuk membuat usaha dalam bidang kopi luwak, walaupun sudah pernah ada investor yang menawarkan kerjasama untuk membangun usaha kopi luwak disana, namun pihak daya tarik wisata Hidden Canyon Beji Guwang sudah menolak tawaran tersebut dengan alas an agar usaha-usaha yang ada di daya tarik wisata Hidden Canyon Beji Guwang ini tetap seratus persen bersifat usaha lokal. Saat ini tim persiapan juga sedang menjalankan beberapa pembenahan dan pembangunan fasilitas baru di daya tarik wisata Hidden Canyon Beji Guwang yakni penataan parkir, pembuatan kantor atau ruangan manager, pembuatan lobby, penambahan toilet baru baik itu shower maupun toilet duduk dimana akan dibuat dekat dengan jalan keluar yang melalui area sawah tersebut dengan tujuan agar wisatawan yang sudah habis berkujung bisa langsung membersihkan diri dan mengganti pakaian sehingga nanti sehabis datang dari tebing Hidden Canyon bisa langsung ke area parkir dan tidak perlu melewati tempat pembelian karcis tiket masuk untuk mencari toilet. Semua pembangunan tersebut berasal dari dana desa, bantuan pemerintah Kabupaten Gianyar yang didapat lewat permohonan melalui DPU (Dinas Pekerjaan Umum) dan dana dari penghasilan daya tarik wisata Hidden Canyon Beji Guwang yang telah disetujui digunakan dan dimanfaatkan melalui kesepakatan bersama di rapat evaluasi akhir tahun dan juga pembenahan kios dagang menjadi restaurant yang memenuhi standar dari sisi tampilan dan kebersihannya.

\section{PENUTUP}

\subsection{Simpulan}

Berdasarkan penelitian yang telah dilakukan dapat disimpulkan bahwa didalam pengembangan daya tarik wisata Hidden Canyon Beji Guwang, sangat dapat dilihat dari keterlibatan dan partisipasi masyarakat lokal setempat yang secara langsung mengembangkan daya tarik wisata tersebut, dimana masyarakat lokal Desa Guwang berpartisipasi penuh didalam pengembangan daya tarik ini. Mulai dari pekerja-pekerja yang ada hingga pengelola daya tarik tersebut merupakan 100 persen masyarakat lokal Desa Guwang. Karena daya tarik wisata Hidden Canyon Beji Guwang masih baru saja dikembangkan dan 
disiapkan oleh Desa Adat dan Desa Dinas Guwang, maka dampak ekonomi dari pengembangan daya tarik tersebut yang muncul hanya baru dampak positifnya. Secara garis besar, pengembangan daya tarik wisata Hidden Canyon Beji Guwang ini sangat bermanfaat dalam konteks ekonomi untuk masyarakat lokal Desa Guwang khususnya masyarakat Desa Guwang yang putus sekolah baik itu di jenjang SD, SMP maupun SMA karena masyarakat yang terlibat dan bekerja di daya tarik wisata ini merupakan masyarakat yang putus sekolah. Hal ini dimaksudkan agar membantu mengurangi angka pengangguran yang diakibatkan oleh minimnya pendidikan yang ditempuh.

\subsection{Saran}

Berdasarkan hasil dan pembahasan sebelumnya, maka saran yang dapat diberikan adalah :

a. Saran yang bisa peneliti berikan untuk pihak pengelola daya tarik wisata Hidden Canyon Beji Guwang yakni agar terus meningkatkan sumber daya manusia yang bekerja disana melalui pelatihan seharihari dan lain-lain. Pihak pengelola juga diharapkan agar lebih menjalin

\section{DAFTAR PUSTAKA}

Anonim. 2009. Undang-Undang RI No.10 Tahun 2009 Tentang Kepariwisataan.

Bungin, Burhan. 2007. Penelitian Kualitatif. Jakarta: Pramedia Group

Deviyanti, Dea. 2013. Studi tentang Partisipasi Masyarakat dalam Pembangunan di Kelurahan Karang Jati, Kecamatan Balikpapan Tengah, eJurnal Administrasi Negara. Vol. 1. No. 2.

Hermawan, Hary. 2017. Dampak Pengembangan Desa Wisata Nglanggeran Terhadap Ekonomi Masyarakat Lokal. eJurnal Pariwisata. Vol. 3 No.2

Juliansyah, Noor. 2011. Metodelogi Penelitian. Jakarta: Prenada Media Group

Koentjaraningrat. 2011. Pengantar Antropologi I. Jakarta: Rineka Cipta

Pitana, I Gde dan Surya Diarta, I Ketut. 2009. Pengantar Ilmu Pariwisata. Yogyakarta: Penerbit Andi

Sugiyono. 2005. Metode Penelitian Administrasi. Bandung: Alfabeta

Umar, Husein. 2003. Metode Penelitian Untuk Skripsi dan Tesis Bisnis. Jakarta: PT. Gramedia Pustaka

Sumber lain :

https://www.justgola.com/a/hidden-canyon-beji-

guwang-1978058697 Diakses pada tanggal 13 Maret

2017 komunikasi ke pihak pemerintah agar daya tarik wisata Hidden Canyon Beji Guwang ini kedepannya akan terus tetap berjalan sesuai dengan harapan.

b. Saran yang bisa peneliti berikan untuk pihak pemerintah yakni agar lebih meningkatkan kerjasama serta komunikasi dengan pihak pengelola setempat. Pemerintah juga diharakan dapat memberikan asuransi kepada para pekerja yang bekerja di daya tarik wisata Hidden Canyon Beji Guwang, seperti yang diketahui bahwa pekerja disana harus setiap hari turun dan naik tebing untuk menghantar dan memandu wisatawan yang datang dimana sangat rawan terjadi kecelakaan.

c. Saran peneliti selanjutnya diberikan untuk masyarakat Desa Guwang agar selalu mengawasi atau memantau keberlangsungan pengembangan daya tarik wisata Hidden Canyon Beji Guwang. Mengingat tujuan daya tarik wisata ini yang sangat positif yakni agar dapat mensejahterakan masyarakat lokal sekitar dan masyarakat merupakan salah satu stakeholder terpenting agar suatu destinasi wisata dapat berjalan kedepannya. 